\title{
Multisystem inflammatory syndrome in children; a rare case found in Covid-19 pandemic
}

\author{
Mukesh Kumar Jain ${ }^{1}$, Jyoti Ranjan Behera ${ }^{1}$, Bandya Sahoo ${ }^{2}$, Reshmi Mishra ${ }^{3}$, Sagar Parida ${ }^{4}$, Sibabratta \\ Patnaik $^{3}$
}

Sri Lanka Journal of Child Health, 2021; 50(3): 552-554

DOI: http://doi.org/10.4038/sljch.v50i3.9747

(Key words: Inflammation, multisystem, IVIG, d-Dimer)

\section{Introduction}

In April 2020, a group of children with hyperinflammatory shock were reported in England. Now many cases have been reported from across the world. We here report a case of Multisystem Inflammatory Syndrome in Children (MIS-C) detected in the Odisha state of India.

\section{Case report}

A girl aged 10 years presented with high fever with loose motions for 2 days and repeated episodes of seizures for the last 6 hours. In emergency, she was found to be obtunded with a Glasgow Coma Scale (GCS) of 6 , an oxygen saturation of $87 \%$ in room air, a heart rate $128 / \mathrm{min}$, a respiratory rate $26 / \mathrm{min}$ and blood pressure of $82 / 42 \mathrm{~mm} \mathrm{Hg}$. She was managed as a case of septic shock, with oxygen by non-rebreathing mask, normal saline bolus and adrenalin infusion at a dose of $1 \mathrm{mcg} / \mathrm{kg} / \mathrm{min}$. She was intubated and ventilated. She was managed with parenteral meropenem, vancomycin, acyclovir and levetiracetam. Investigations revealed a haemoglobin $(\mathrm{Hb})$ level of $9.3 \mathrm{~g} / \mathrm{dl}$ and a total leucocyte count (TLC) of 20,300/cu mm (neutrophil $70 \%$ and lymphocyte $28 \%$ ). Kidney function was normal. C-reactive protein (CRP) was $79.7 \mathrm{mg} / \mathrm{L}$, serum ferritin $119 \mathrm{ng} / \mathrm{mL}$, serum lactate dehydrogenase (LDH) 606.2 U/L and creatine kinase myocardial band (CK-MB) was $52 \mathrm{IU} / \mathrm{L}$.

Reverse transcription polymerase chain reaction (RT-PCR) for Covid19 was sent. 2D-ECHO revealed decreased contractility of heart and $\mathrm{x}$-ray

\begin{tabular}{l}
\hline${ }^{1}$ Assistant Professor, ${ }^{2}$ Professor, ${ }^{3}$ Associate \\
Professor, Department of Pediatrics, ${ }^{4}$ Fellow, \\
Pediatric Intensive Care, Kalinga Institute of \\
Medical Sciences, Bhubaneswar, India \\
*Correspondence: drsbpatnaik45@gmail.com
\end{tabular}

https://orcid.org/0000-0002-3020-4229

(Received on 30 August 2020: Accepted after revision on 16 October 2020)

The authors declare that there are no conflicts of interest

Personal funding was used for the project.

Open Access Article published under the Creative

Commons Attribution CC-BY (CC)

of chest showed cardiomegaly with a cardio-thoracic ratio of 0.6. She continued to have fever with spikes despite all treatment. Her repeat tests after 3 days revealed a Hb level of $7.2 \mathrm{~g} / \mathrm{dL}$, TLC of $8800 / \mathrm{cu} \mathrm{mm}$ (N 78\%), total platelet count 140,000/cu mm, CRP of $210 \mathrm{mg} / \mathrm{L}$, procalcitonin of $95.4 \mathrm{ng} / \mathrm{mL}$, LDH of $1963 \mathrm{U} / \mathrm{L}$, d-Dimer of $3.98 \mathrm{mcg} / \mathrm{mL}$, serum ferritin of $91.4 \mathrm{ng} / \mathrm{mL}$, erythrocyte sedimentation rate (ESR) of $26 \mathrm{~mm}$ in $1^{\text {st }}$ hour and triglyceride level of 188 $\mathrm{mg} / \mathrm{dL}$. Later RT-PCR for Covid-19 came out to be positive while antibody to Covid-19 was negative. Evaluation for fever in the form of malaria parasite immune-chromatography test (MP ICT), scrub typhus IgM, dengue IgM, blood culture, ultrasonography (USG) of abdomen, and urine examination did not reveal any abnormalities. Magnetic resonance imaging (MRI) of brain revealed cerebral oedema. After reviewing all reports, diagnosis of MIS-C was made as per criteria laid down by WHO. She was managed with intravenous immunoglobulin (IVIG) $2 \mathrm{~g} / \mathrm{kg}$ over 24 hours, along with methyl prednisolone $2 \mathrm{mg} / \mathrm{kg} /$ day in 2 divided doses for 7 days. She was weaned off inotropes in 4 days and extubated on day 7. She was re-intubated on day 9 because of low GCS. She continued to remain on the ventilator because of low GCS, her ventilator requirement gradually increasing and she finally expired on day 19 of admission.

\section{Discussion}

Different organisations give different definition for MIS-C. The definitions by Centres for Disease Control and Prevention (CDC), World Health Organisation (WHO) and the Royal College of Paediatrics and Child Health $(\mathrm{RCPCH})$ are given in a tabular form (Table 1) for better understanding ${ }^{2}$. Our child had fever for 2 days, along with loose motions and developed seizures later. She was in shock with myocardial dysfunction with raised CPK-MB. Inflammatory markers were elevated. RTPCR for Covid-19 was positive and all possible causes of infection were ruled out. Thus she fit into the diagnosis of MIS-C. The exact pathophysiology of MIS-C is not known, but there are many hypotheses. The cytokine storm leading to multiorgan dysfunction and raised inflammatory markers may be due to antibody mediated immune enhancement just like dengue fever ${ }^{3}$. Direct anti- 
tissue antibody and immune complex mediated tissue injury and delayed cytokine surge are the other proposed hypotheses ${ }^{4,5}$.

Table 1: Definitions for Multisystem Inflammatory Syndrome in Children

\begin{tabular}{|c|c|c|c|}
\hline & $\begin{array}{c}\text { WHO } \\
\text { (MIS-C) }\end{array}$ & $\begin{array}{c}\text { CDC } \\
(\text { MIS-C) }\end{array}$ & $\begin{array}{l}\text { RCPCH } \\
\text { (PIM-TS) }\end{array}$ \\
\hline Age & $0-19$ years & $<21$ years & Child (age not specified) \\
\hline $\begin{array}{l}\text { Main } \\
\text { features }\end{array}$ & $\begin{array}{l}\text { Two of the following: } \\
\text { (A) Rash or bilateral non-purulent } \\
\text { conjunctivitis or mucocutaneous inflammation } \\
\text { signs (oral, hands, or feet); } \\
\text { (B) Hypotension or shock; } \\
\text { (C) Features of myocardial dysfunction, } \\
\text { pericarditis, valvulitis, or coronary } \\
\text { abnormalities (including echocardiogram } \\
\text { findings or elevated troponin or N-terminal pro } \\
\text { B-type natriuretic peptide); } \\
\text { (D) Evidence of coagulopathy (elevated } \\
\text { prothrombin time, partial thromboplastin time, } \\
\text { and elevated D-dimers); and } \\
\text { (E) acute gastrointestinal problems (diarrhoea, } \\
\text { vomiting, or abdominal pain }\end{array}$ & $\begin{array}{l}\text { Clinically severe illness requiring } \\
\text { hospitalisation; and multisystem (two } \\
\text { or more) organ involvement (cardiac, } \\
\text { renal, respiratory, haematological, GI, } \\
\text { skin, or neurological) }\end{array}$ & $\begin{array}{l}\text { Single or multiple organ } \\
\text { dysfunction } \\
\text { Shock or respiratory, renal, } \\
\text { gastrointestinal, or } \\
\text { neurological disorder; } \\
\text { additional features }\end{array}$ \\
\hline Inflammation & $\begin{array}{l}\text { Fever and elevated inflammatory markers for } 3 \\
\text { days or more }\end{array}$ & $\begin{array}{l}\text { Fever }>24 \text { hours and elevated } \\
\text { inflammatory markers }\end{array}$ & $\begin{array}{l}\text { Fever and elevated } \\
\text { inflammatory markers }\end{array}$ \\
\hline Exclusion & Other microbial cause of inflammation & Other plausible alternative diagnoses & Any other microbial cause \\
\hline $\begin{array}{l}\text { SARS-CoV-2 } \\
\text { status }\end{array}$ & $\begin{array}{l}\text { Positive RT-PCR, antigen test, or serology; or } \\
\text { any contact with patients with COVID-19 }\end{array}$ & $\begin{array}{l}\text { Positive RT-PCR, serology, or antigen } \\
\text { test; or COVID-19 exposure within the } \\
\text { past } 4 \text { weeks before symptom onset }\end{array}$ & $\begin{array}{l}\text { RT-PCR positive or } \\
\text { negative }\end{array}$ \\
\hline
\end{tabular}

In the study published in the Morbidity and Mortality Weekly Report (MMWR) on August 7, 2020, almost all (99\%) had evidence of SARS Cov2 infection ( $46 \%$ were serology positive, $25 \%$ only RTPCR positive and $27 \%$ both serology and RTPCR positive), while in $1 \%$ no test was done but epidemiologic link was present. They were broadly divided into 3 groups. First group (35\%) presented with multi-organ dysfunction, shock, myocarditis, where $98 \%$ were serology positive with or without RTPCR being positive. The second group (30\%) presented as pneumonia and ARDS and were mostly RTPCR positive (86\%). The last group (35\%) usually behaved as Kawasaki disease with maximum coronary affection. Majority in this group were antibody positive (63\%) while $34 \%$ had both positive $^{6}$. In the paper published from UK, out of total 78 cases, $76 \%$ required IVIG, $73 \%$ required steroids, while $22 \%$ needed biologic immune modulators. Forty one percent needed prophylactic anticoagulants and 58\% required aspirin ${ }^{7}$.

Our child was treated with IVIG, steroids, low molecular weight heparin and other supportive treatment. She did improve and was even extubated after the $7^{\text {th }}$ day. However, because of the low GCS she was re-intubated. The death might be due to consequences of prolonged ventilation and airway related issues.

MIS-C is a rare and new clinical condition seen in children during this Covid-19 pandemic. In any child presenting with fever, multiorgan dysfunction and very high inflammatory markers, MIS-C should be thought of and the child evaluated accordingly.

\section{References}

1. Paediatric Intensive Care Society. PICS Statement: increased number of reported cases of novel presentation of multisystem inflammatory disease. April 27, 2020. Available from:

https://picsociety.uk/wpcontent/uploads/20 20/04/PICS-statement-re-novel-KDC19presentation-v2-27042020.pdf (accessed May 16, 2020).

2. Jiang L, Tang K, Levin M, Irfan O, Morris SK, Wilson K, et al. COVID-19 and multisystem inflammatory syndrome in children and adolescents. The Lancet Infectious Diseases Published 17 $7^{\text {th }}$ August, 2020.

https://doi.org/10.1016/S14733099(20)306 $51-4$

3. Katzelnick LC, Gresh L, Halloran ME, Mercado JC, Kuan G, Gordon A, et al. Antibody-dependent enhancement of severe dengue disease in humans. Science 2017; 358(6365): 929-32. https://doi.org/10.1126/science.aan6836 PMid: 29097492 PMCid: PMC5858873 
4. Wang S-F, Tseng S-P, Yen C-H, Yang J-Y, Tsao $\mathrm{CH}$, Shen $\mathrm{C}-\mathrm{W}$, et al. Antibodydependent SARS coronavirus infection is mediated by antibodies against spike proteins. Biochemical and Biophysical Research Communications 2014; 451(2): 208-14.

https://doi.org/10.1016/j.bbrc.2014.07.090

PMid: 25073113 PMCid: PMC7092860

5. Rowley AH. Understanding SARS-CoV-2related multisystem inflammatory syndrome in children. Nature Reviews Immunology 2020; 20: 453-4.

https://doi.org/10.1038/s41577-020-0367-

5

PMid: 32546853 PMCid: PMC7296515

6. Hrapcak S, Datta D, Morris SB, Clarke K, Belay E. COVID-19-associated multisystem inflammatory syndrome in children - United States, March-July 2020.
Morbidity and Mortality Weekly Report 2020; 69(32): 1074-80.

https://doi.org/10.15585/mmwr.mm6932e

2

PMid: 32790663 PMCid: PMC7440126

7. Davies P, Evans C, Kanthimathinathan HK, Lillie J, Brierley J, Waters G, et al. 2020. Intensive care admissions of children with paediatric inflammatory multisystem syndrome temporally associated with SARS-CoV-2 (PIMS-TS) in the UK: a multicentre observational study. Lancet Child \& Adolescent Health Published $1^{\text {st }}$ January, 2020.

https://doi.org/10.1016/S23524642(20)302 $15-7$ 